\title{
Motives for Semantic Borrowing and Calquing from Old Chinese into Japanese
}

\author{
Matthew Zisk ${ }^{*}$ \\ LSA Annual Meeting, Minneapolis, January 2-5, 2014
}

1. Introduction. The influence of the Chinese language ${ }^{1}$ on Japanese over the past two millennia has been immense, ranging from the wholesale adoption of the Chinese writing system (kanji), to the adoption of Chinese as a literary language (kanbun) and the borrowing of multitudes of Chinese words (kango). In the past, the main focus of Chinese-Japanese borrowing has been on loanwords and loanword phonology (Yamada 1958, NINJL 2006, etc.). In addition to loanwords, a large number of substitution-based loans (calques and semantic loans) have also occurred through Chinese-Japanese contact. Although previous studies have acknowledged the existence of such substitution-based loans (Yamada 1935, Satō 1981, Ōtsubo 1981), until recently, very little research has been available on the subject and no thorough analysis of how such loans occur. More recently, Ishizuka $(2005,2012,2013)$ and Zisk $(2009,2010,2012,2013 \mathrm{abc})$ have revisited the topic, but the motives behind such substitution-based loans still remain largely unclear.

Perhaps the most unique feature surrounding substitution-based loans is the method in which these loans entered the Japanese language. The vast majority (if not all) substitutions from Chinese occurred through kanbun kundoku (translated by Whitman et al. 2010 as 'vernacular reading'), a systematic process in which Chinese texts are translated word-by-word spontaneously through a series of reading glosses. Through vernacular reading, one can interpret Chinese texts in Japanese with little to no knowledge of the grammar and syntax of the original language. The goal of this paper is to look into the motives of such substitution-based loans.

2. A typology of linguistic borrowing from Old Chinese into Japanese. Linguistic borrowing is typically broken down into two main categories: 1 . Importation, in which phonetic/lexical items are directly transferred from donor to recipient language, and 2. Substitution, in which items of the donor language are reproduced indirectly using lexicon of the recipient language (Betz 1949, 1959, Haugen 1950, 1969, Duckworth 1977). Substitutions in Chinese-Japanese contact can be further broken down into loan grammar, in which Japanese grammar and syntax is influenced by Chinese, loan coinages, in which new words are formed based on Chinese models, and loan meanings, in which the sense of a word is expanded or constricted to match a Chinese model.

Loan grammar consists of loan POS (part of speech)-shifts, where a word's lexical category is altered to match a Chinese model and loan syntax, where word order is altered to match Chinese syntax. Loan coinages consist of loan translations, in which a new compound (loan compound) or phrase (loan phrase) is formed based off of the direct translation of a Chinese model; loan renderings, in which a new compound or phrase is formed based off of a partial translation; loan creations, where a new word is formed independent of the Chinese source but nonetheless due to cultural contact; annotational renderings, in which a new compound is formed based on a direct or approximate translation of an annotation in a text or dictionary describing the meaning of a Chinese character; and etymological renderings, in which a compound is formed by directly translating each component of a Chinese character.

\footnotetext{
* Acknowledgements: This work was supported by JSPS KAKENHI Grant Number 25870077.

Authors: Matthew Zisk, Yamagata University (zisk@yz.yamagata-u.ac.jp)

${ }^{1}$ In this paper, the term 'Old Chinese' is used to refer to all pre-modern variants of the language and not any particular linguistic period. Unless otherwise stated, the term 'Chinese' is used to refer to Old Chinese in the above sense.
} 
3. Calquing and semantic borrowing in vernacular reading. Above, I have outlined the various types of Chinese loans observed in the Japanese language. In the following section, I will take a more detailed look at substitution-based loans using actual examples.

3.1 EXAMPLE \#1: IFA-KU (SOV $\rightarrow$ SVO) (LOAN SYNTAX). Since Japanese is an SOV language and Chinese is an SVO language, it was necessary to invert either the Chinese or Japanese word order when vernacularly reading Chinese texts. In many cases, inversion glosses consisting of numerals or symbols were added to the text and word order was inverted to fit Japanese syntax. However, in a few cases, the glossator would use the nominal form (irrealis $+-k u$ ) of a verb to form a SVO sentence, preserving the original Chinese word order. While this construction was used with a number of verbs, it was by far most frequently used with the verb for 'to say,' ifu. For example, in vernacular reading, the Chinese verb 日 yue ('to say') at the beginning of a quotation would typically be glossed with the nominal form of ifu $(=i f a-k u)$ :

(1) Bonwau no ifa-ku, "Kono genke no fito fa karada kore aru ni arazu..." Brahmā GEN say.NMNL this māyā GEN person TOP body this have LOC have.NEG 'Brahmā said, "This person is a māyā ['illusion'] and has no physical form...' Konkōsaishōmyōōkyō [Golden Light Sutra] Saidaiji M.S. vol. 5 (early 9C) ${ }^{2}$

In the example above, $\mathrm{Ch}$. 曰 yue is glossed verbatim, SVO word order intact, with Jp. ifa-ku. While examples of inversion (or more appropriately, anastrophe) can be found in Old-Middle Japanese prose and verse (wabun and waka), it is typically used as a literary technique to express emphasis and we find very few examples of a verb such as ifu being used to open a quotation.

4.2 EXAMPLE \#2: OYOBI / NARABI-NI. Oyobu ('to reach') and narabu ('to be parallel to') are two Japanese verbs which underwent a major shift both semantically and morphologically in vernacular reading. In Old-Middle Japanese prose and poetry, these verbs are used to express the two senses listed above; however, through continuous use of these two verbs to gloss $\mathrm{Ch}$. 及 $\mathrm{ji}$ and 並 bing, possessing the same two verbal senses as oyobu and narabu respectively, they each acquired the conjunctional usage ('and') that 及 $j i$ and 並 bing also possess:

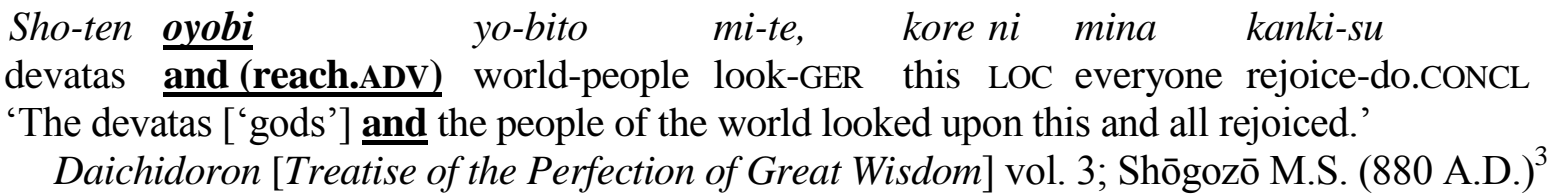

In the example above, the part of speech of oyobu is morphologically altered by using the adverbial form of the verb to form a conjunction.

4.3 EXAMPLE \#3: TORAFE-BITO / TORAFARE-BITO. The compounds torafe-bito (capture.ADV-person) and torafare-bito (be.captured.ADV-person) each denote a 'prisoner' and are found primarily in Chinese-Japanese glosses or Chinese character dictionaries as a gloss for $\mathrm{Ch}$. 囚人 qiú-rén (captureperson > prisoner) or 囚徒 qiú-túi (capture-fellow > prisoner):

(3) Arayuru torafe-bito (Ch. 囚徒 qiú-túi), jifu ni si-te iti wo mattaku-se-zu.

All prisoner ten LOC do-GER one ACC endure-do-NEG.CONCL

'Out of all the prisoners, not even one in ten could endure (the pain).'

\footnotetext{
${ }^{2}$ Kasuga (1985).

${ }^{3}$ Kobayashi (2012).
} 
Both torafe-bito and torafare-bito are not found in traditional Japanese prose and verse and make their first appearance in the Chinese-Japanese glosses. Considering that the concept of a prisoner of the law was originally foreign to Japan and introduced from China during the seventheighth century, it is only natural that these words first appear in glosses, and thus highly probable that they were coined as loan translations of 囚人 qiú-rén and 囚徒 qiú-túi.

4.4 EXAMPLE \#4: NOSU. In modern Japanese, the verb noseru (Old-Middle Japanese nosu) has the following two senses: 1. 'to put in/onto a vehicle, horse, or other mountable animal'; 2. 'to record (an event, a name, etc.).' When we look at the meaning of nosu in Old and Early Middle Japanese prose and verse, we find that nosu is used exclusively for sense \#1; however, if we are to observe Chinese-Japanese glosses from the same period, we find this word taking on the new sense \#2 as a vernacular reading for $\mathrm{Ch}$. 載 $z a \check{i}$ :

Furuki fon ni naki tokoro wo, kono fumi ni tomo-ni nose-tari. old.ADN book LOC nonexistant.ADN place ACC this text LOC together-LOC record-PER.CONCL '(I) have recorded here in this tome that which is not in the ancient books.'

$$
\begin{array}{r}
\text { Daijōdaishūjizōjūiringyō [Ten Chakras of Kșitigarbha, } \\
\text { Mahāyāna Great Collection utra] Tōdaiji Library M.S. Preface (892 A.D.) }{ }^{5}
\end{array}
$$

Since 載 zăi possesses the same sense \#1 as Japanese nosu, 'to put on/into a vehicle,' it is highly likely that nosu was chosen as a vernacular reading for 載 ză $i$ and then expanded to cover the sense 'to record,' which at the time had no equivalent in Japanese, as the recording of documents was a novel concept in Japan up until the adoption of Chinese characters and literature.

4.5 EXAMPLE \#3: AKASU. The verb akasu is used to express the following two senses in Modern Japanese: 1. 'to spend the night (doing something)' and 2. 'to clarify.' If we look at Old-Middle Japanese prose and verse, we find akasu used primarily for sense \#1; however, when looking at Chinese-Japanese glosses, we find that akasu is frequently used as a gloss for 明 ming to express the act of clarification or enlightening.

(5) Kofe no naka ni mimeu no kata no sange no fofu akasu... voice GEN inside LOC marvelous GEN gāthā GEN ksama GEN doctrine clarify.ADN ...'Within the voice (of the gong), a marvelous gāthā ['verse'] on the doctrine of ksama ['confession and repentance'] was revealed.'

Konkōmyōsaishōōkyō [Golden Light Sutra] Saidaiji M.S. vol. 2 (early 9C) ${ }^{6}$

This usage of akasu as a gloss for 明 ming is predominant throughout Early Middle Japanese manuscripts of Buddhist texts; however, we very rarely see akasu used in this sense in traditional prose and verse. Therefore, it is only logical to conclude that akasu borrowed the sense 'to clarify' from 明 ming through the vernacular reading process in a fashion similar to nosu.

While 明 ming does not possess the sense 'to spend the night' that we see in akasu, it is commonly used in Tang poetry, as a transitive verb with the sense, 'to light up' or 'to illuminate.' The root of akasu, ak-, also expresses this meaning light and brightness (cf. akasi: 'bright') and thus,

\footnotetext{
${ }^{4}$ Koten Hozonkai (1938). Interpreted text (kakikudashibun) reconstructed by author.

${ }^{5}$ Nakada (1979). Nakada mistakenly interprets $c h \bar{u}$ 注 as $j \bar{u}$ 住.

${ }^{6}$ Kasuga (1985).
} 
it is believed that through analogy of this fundamental sense of light and brightness, seen in both akasu (or more specifically, the root ak-) and 明 ming, akasu came to be commonly used as a vernacular reading for 明 ming and borrowed sense \#2 ‘to clarify' from this character.

5. Motives for substitution-based loans in vernacular reading. Looking at the five examples given above, we can see the following two characteristics, each of which could be said to be a motivating factor of the initial borrowing: loan coinages and loan meanings tend to be deeply linked semantically with cultural adoption and loan grammar tends to be heavily connected to the practice of prescribing set vernacular readings ('prescribed readings') to Chinese characters.

5.1 CULTURAL ADOPTION. Each of the loan meaning examples given above represent cultural concepts: nosu is an expression of writing and akasu is an expression of elucidation, both relatively new concepts in Japan at the time of the adoption of Chinese characters and writing. While native expressions for writing did exist prior to Chinese contact, these expressions were too broad or general to express the relatively specific expressions used in Chinese literature. For example, the word $k a k u$ is attested back to the Old Japanese period; however, $k a k u$ is used to express the general concept of writing including drawing, sketching, painting, etc. and is thus too broad to adequately express the more specialized meaning of 載 zăi . There were no so-called expressions of elucidation prior to Chinese contact, but there were similar expressions. For example, the word tutafu represents the transmission of knowledge from one person to another; however, tutafu tends to focus on the transmission of practical knowledge, such as how to play an instrument, rather than pure theoretical knowledge, which is usually the object of 明 ming.

5.2 PRESCRIBED READING. In the vernacular reading practice, each Chinese character is typically given a kun or native reading which is used to render the character in Japanese. Chinese characters tend to possess several distinct meanings and due to the isolating nature of the language, Chinese characters (or morphemes) are often used to express more than one part of speech. Thus, it was common for Japanese glossators to ascribe multiple readings to a single character depending on meaning and part of speech. Over time, however, through years of glossing and dictionary traditions, a set of established readings, known as teikun ('prescribed readings'), which were easily recallable by both glossator and reader came to develop. While it was still common for a single character to have multiple prescribed readings, in many cases, prescribed readings would cover much more territory, semantically, morphologically, and at times syntactically, than their traditional Japanese prose and verse counterparts. Ritual adherence to such prescribed readings in vernacular reading eventually lead to the development of unnatural and bizarre constructions, such as word order inversions (SOV > SVO: ifaku) and shifts in part of speech (oyobi), as well as a large number of not impossible but improbable semantic extensions.

6. Conclusion: Vernacular reading as a contributing factor to the formation of Japanese. As the examples in this paper demonstrate, the influence of Chinese on the Japanese language is massive, covering, but not limited to, vocabulary (loanwords), semantics (loan meanings), morphology (loan POS-shifts), and syntax (loan syntax). While in Indo-European languages, the main motive for substitution-based loans is usually said to be homonymy between the donor and recipient language, in Japanese, we see zero homonymy (since Chinese and Japanese are genetically unrelated), but instead, vernacular reading and prescribed readings as the major motive for substitution-based loans. This heavy adherence to prescribed readings and over-systematization of the vernacular reading process gave rise to the formation of highly metaphrastic constructions and improbable semantic expansions, greatly contributing to the formation of the Japanese language. 


\section{Sources}

Kasuga, Masaji. 1985. Saidaijibon Konkōmyōsaishō’oōkyō-koten no Kokokugogakuteki Kenkyū [Japanese Linguistic Research on the Golden Light Sutra, Saidaiji M.S.]. In: Kasuga, Kazuo (ed.). Kasuga Masaji Chosakushū [The Collected Works of Masaji Kasuga]. Supplement. Tokyo: Benseisha.

Kobayashi, Yoshinori. 2012. Shoki Kundokugo Taikei [An Overview of Early Heian Era Gloss Lexicon]. Heian Jidai no Bussho ni Motodzuku Kanbunkundokushi no Kenkyū [Research on the History of the Vernacular Reading of Buddhist Texts in the Heian Era]. Vol. 3. Tokyo: Kyūko Shoin.

Koten Hozonkai (ed.). 1938. Ishiyamadera-zō Koshōbon Kongouhannyashūgenki [Records of the Miraculous Manifestations Revealed to Adherers of the Diamond Sutra Gloss, Ishiyamadera M.S.]. Tokyo: Koten Hozonkai.

Nakada, Norio. 1979. Kaiteiban Kotenbon no Kokugogakuteki Kenkyū: Yakubunhen; Sakuinhen [Japanese Linguistic Research on Old Glosses, Revised Edition: Interpreted Texts; Concordance]. Tokyo: Benseisha.

\section{References}

Betz, Werner. 1949. Deutsch und Lateinisch: Die Lehnbildungen der Althochdeutschen Benediktinerregel. Bonn: H. Bouvier u. Co.

Betz, Werner. 1959. Lehnwörter und Lehnprägungen im Vor- und Frühdeutschen. In: Maurer, Friedrich and Friedrich Stroh (eds.). Deutsche Wortgeschichte. 2nd ed. Berlin: Schmidt, Vol. 1, pp. 127-147. Rpr. in 1974 by Hermann, Paul. Grundriss der Germanischen Philologie. Berlin / New York: Walter de Gruyter.

Duckworth, David. 1977. Zur terminologischen und systematischen Grundlage der Forschung auf dem Gebiet der english-deutschen Interferenz. In: Kolb, Herbert and Hartmut Lauffer (eds.). Sprachlich Interferenz: Festschrift für Werner Betz zum 65. Geburststag. Tübingen: Max Niemeyer Verlag. pp. 36-56.

Haugen, Einar. 1950. The Analysis of Linguistic Borrowing. Language. Vol. 26, No. 2: pg. 210-231.

Haugen, Einar. 1969. The Norwegian language in America. 2nd. ed. Ontario: University of Indiana Press.

Ishidzuka, Harumichi. 2005. Nihongo Hyōgen no Gendōryoku to shite no Kanbunkundoku [Vernacular Reading as a Source of Innovation for Japanese Expressions]. Hikaku Nihongaku Kenkyū Sentā Kenkyū Nenpō [The Center for Comparative Japanese Studies Annual]. Vol. 1. pg. 75-80.

Ishidzuka, Harumichi. 2012. Ibunka Komyunikēshon to shite no Kanji Jouhou to Kanbun Kundoku [Kanji Information and Kambun Glosses as a Means of Intercultural Communication]. Xiu, Gang and Li Yun (eds.). Xīnshídài dí Shìjiè Rìyüjiàoyù Yánjīū [Research on New-age International Japanese Language Education]. Beijing: Higher Education Press. pg. 26-34.

Ishidzuka, Harumichi. 2013. Nihongo Hyōgen no Gendōryoku to shite no Kanbunkundoku [Vernacular Reading as a Source of Innovation for Japanese Expressions]. Presentation at the Society for Research in Kunten Language $108^{\text {th }}$ Meeting, May 26, 2013.

National Institute for Japanese Language and Linguistics (NINJL). 2006. Gendai Zasshi 200 Man-ji Gengo Chōsa Goihyō [Vocabulary Chart of Linguistic Survey of Two Million Words from Modern Magazines]. NINJL. Available online at: http://www.ninjal.ac.jp/archives/goityosa/ (accessed 12.28.2013).

Ōtsubo, Heiji. 1981. Heian Jidai ni okeru Kunten-go no Bunpou [The Grammar of Gloss-specific Lexicon in the Heian Period]. Tokyo: Kazama Shobo.

Satō, Kiyoji. 1981. Kanji to Nihongo: Kanji Jikun no Kenkyū [Japanese and Kanji: Research on Japanese Ascribed Readings of Kanji]. Yamanashi Eiwa Tanki Daigaki Kokubungaku Kenkyūshitsu [Yamanashi Eiwa Junior College Department of Japanese Literature] (ed.). Yamanashi Eiwa Tankidaigaku Sōritsu Jūgo Shūnen Kokubungaku Ronshū [Collected Essays on Japanese Literature Commemorating the Fifteenth Anniversary of Yamanashi Eiwa Junior College]. Tokyo: Kazama Shoin. pg. 287-305.

Whitman, John et al. 2010. Towards an International Vocabulary for Research on Vernacular Readings of Chinese Texts (漢文訓讀 Hanwen Xundu). SCRIPTA. Vol. 2. pg. 61-84.

Yamada, Yoshio. 1958. Kokugo no Naka ni okeru Kango no Kenkyū, Teiseiban [Research on Sino-Japanese Lexicon in the Japanese Language, Revised Edition]. Tokyo: Hōbunkan.

Zisk, Matthew. 2009. Wago ni taisuru Kanji no Eikyou: Sha-ji to Utsusu no Kankei wo Ichirei ni [The Influence of Kanji on Japanese Native Words: A Look at Chinese Xiě (写) and Japanese Utsusu]. Kanji Kyouiku Kenkyū [Kanji Education Research]. Vol. 10: pg. 6-45.

Zisk, Matthew. 2010. Imi no Ue no Kambun Kundoku-go: Wago Arafasu ni taisuru Kanji Cho no Imi-teki Eikyou [Semantic Borrowing in Sino-Japanese Glosses: The Semantic Influence of Chinese Zhù (著) on Japanese Arafasu]. 
Kunten-go to Kunten-shiryou [Diacritical Language and Diacritical Materials]. Vol. 125: pg. 53-78.

Zisk, Matthew. 2012. Keimou-Hyougen ni okeru Kanji wo Baikai to shita Imi-Shakuyou: Wago Akasu no Imi Henka Katei ni okeru Mei-ji no Eikyou [Kanji-Inspired Semantic Loans in Expressions of Enlightenment: The Influence of Chinese Ming (明) in the Semantic Shift of Japanese Akasu]. Kokugo Moji-shi no Kenkyū [Research on the History of Japanese Writing]. Vol. 13: pg. 105-126.

Zisk, Matthew. 2013a. Nihongo ni okeru Kanji wo Baikai to shita Imishakuyō no Kenkyū [Research on Semantic Borrowing via Chinese Characters in Japanese]. Dissertation. Tohoku University Graduate School of Arts and Letters.

Zisk, Matthew. 2013b. Nihongo ni okeru Kanji / Kanbun wo Baikai to shita Gengoshakuyō Moderu no Kōchiku [The Construction of a Borrowing Model for Kanji / Kanbun-induced Loans in Japanese]. Presentation at the Society for Japanese Linguistics 2013 Fall Conference at Shizuoka University, Oct. 10, 2013.

Zisk, Matthew. 2013c. Gengoshakuyō ni okeru Kanbunkundoku to Teikun no Ichiduke [The Role of Vernacular Reading and Prescribed Readings in Linguistic Borrowing]. Presentation at the Japan Society for Historical Linguistics 2013 Conference at Tōhoku University, Dec. 1, 2013. 